\title{
Dilema e experimentação em João do Rio: contribuições ao jornalismo e à literatura
}

\author{
Thaïs de Mendonça Jorge', Rogério Pereira Borges²
}

Resumo: Este trabalho pretende demonstrar que a imenção do jornalismo c a expansão da literatura no Brasil são fenómenos que têm no nascedouro aspectos comuns: a) movimentos artísticos, literários e jornalisticos em escala mundial na virada do século XIX para o XX; b) eclosão de novos gêneros na literatura e no jornalismo, realçando figuras como a de joão do Rio, uma figura que se situa entre o escritor e o jornalista; c c) afirmação do texto noticioso como bem simbólico numa sociedade $\mathrm{cm}$ transformação. É grande a quantidade de escritores que mantiveram carreira jornalística. Hemingway e Orwell; Dostoicvski, Tchetov, Balzac, Vargas L_losa, García Márquez são nomes de vulto da literatura universal que mantiveram vínculos com a imprensa. No Brasil, não foi diferente, com Machado de Assis, José de Alencar, Olavo Bilac e Castro Alves. João Paulo Alberto Coelho Barreto se situou na fronteira entre a ficção $e$ a realidade $c$ inaugurou a reportagem e a crônica no Brasil.

Palavras-chave: João do Rio, jornalismo, literatura, noticia, reportagem, gênero.

\footnotetext{
Abstract: This work intends to demonstrate that journalism and literature in Brazil have common characteristics in their beginning: a) artistic, literary and journalistic activities all over the world, mainly during the transition from XIX to $\mathrm{XX}$ century; b) the development of new genres in literature and journalism, emphasizing names like joão do Rio, a double writer/ novelist and journalist; and c) the assertion of news text in the transformation of the society. There were many writers who also had journalistic jobs. He-

1 Doutora en Comunicaçào pela Universidade de Brasilin, mestra em Ciénciá Politica também pela UnB, docente da Faculdade de Comunicação e do Programa de Pós-Graduaçào dessa universidade. lí jornalista profissional, graduada em Comunicação pela UFNG. Começou carreira no magistério na Universidade Federal Fluminense, em paralelo à atuaçio na grancle imprensa brasilcira.

2 Doutorando $\mathrm{cm}$ Comunicaçào pela Universidade de Brasilia, anestre cm I:studos l_jterários e Lingüistica pela Faculdade de Letras da Universidade Federal de Goińs, graduado on Comunicação Social pela UFG. Docente de Comunicação na Universidade Católica de Goins ć jornalista profissional, responsável pela atca de literatura no jornal O Populor, de Goiania
} 
mingway and Orwell; Dostoievski; Tchekov, Balzac, Vargas Llosa, García Márquez are names in the world literature that maintened conection with the press. In Brazil, it happened the same thing with Machado de Assis, José de Alencar, Olavo Bilac and Castro Alves. João Paulo Alberto Coelho Barreto stays in the limit between fiction and reality: he was responsible for the introduction of reports (stories) in the newspapers, as well as the chronicle style in Brazil.

Keywords: journalism, literature, joão do Rio, news, stories, genres.

Existem histórias que se confundem e por elas circulam personagens que, de alguma forma, acabam por representar a proximidade entre dois campos com trajetórias paralelas. As vizinhanças entre jornalismo e literatura e a atuação de João do Rio nessa fronteira são exemplos disso. É grande a quantidade de escritores que mantiveram carreiras jornalísticas. Ernest Hemingway e George Orwell presenciaram os horrores da Guerra Civil Espanhola como correspondentes de jornais impressos. Defoe, Richardson, Poe, Dostoievski, Tchekov, Balzac, Vargas Llosa, Calvino, Swift, Dickens, Victor Hugo, García Márquez são outros nomes de vulto da literatura universal e que mantiveram profundos vínculos com a imprensa. No Brasil, não foi diferente. Machado de Assis, José de Alencar, Olavo Bilac e Castro Alves, anteriores ou contemporâneos a João do Rio, formam um grupo respeitável de autores que mantiveram atuações simultâneas nos campos do jornalismo e da ficção, muitas vezes unindo as duas, como é o caso da publicação de folhetins em jornais.

De fato, o jornalismo impresso e a literatura aproximamse, intersectam-se, afastam-se, particularmente desde a etapa históriça em que a imprensa ganha sua feição moderna, industrial, a partir da última metade do século passado [XIX]. Entre o jornalismo e a literatura existia em comum, nesses tempos pioneiros da era moderna, o ato da escrita. (...) Por uma condição de proximidade, estabelecida peló elo comum da'escrita, é natural compreender que, mẻsmo intuitivamente ou sem maior rigor metodológico, osijornalistas sentiam-se então inclinados a se inspirar na arte literária para encontrar os seus próprios caminhos de narrar o real. (LIMA, 1995, p. 135). 
Textos feitos para a imprensa escrita e histórias elaboradas com objetivos estéticos mostram aproximações e distanciamentos que solidificam vínculos profundos. São vínculos desde a origem até os efeitos junto aos leitores, passando por questões como linguagem, organização do discurso, tratamento de temas, personagens, aos dogmas da objetividade, imparcialidade e isenção, além de técnicas próprias a quem se dá a missão de redigir notícias e histórias. Todo esse contexto nos auxilia no entendimento do trabalho híbrido entre as duas formas discursivas, empreendido pelo escritor-jornalista João Paulo Alberto Coelho Barreto, o Joào do Rio. Este trabalho pretende demonstrar que a expansão do jornalismo e da literatura no Brasil é fenômeno que tem no nascedouro aspectos comuns: a) movimentos artísticos, literários e jornalísticos em escala mundial; b) eclosão de novos gêneros na literatura e no jornalismo, realçando a figura de João do Rio e sua experiência, tanto como escritor, quanto como jornalista; e c) afirmação do texto noticioso como bem simbólico numa sociedade em transformação.

Adelmo Genro Filho (1989, p. 105) cita Habermas para estabelecer três fases principais do jornalismo. A primeira delas teria cunho mais mercantil, com grande ênfase nos anúncios comerciais. Seria um jornalismo utilitário, em que negociações estariam na pauta dos informativos, em um período de consolidação do capitalismo. Em um segundo momento, o jornalismo teria pendido para um perfil literário. Aqui estão os artigos de fundo, a publicação de grandes polêmicas, a defesa in flamada de idéias por parte dos intelectuais. $O$ caso Dreyfus, na França, com a intensa participação de nomes como Emile Zola, ilustra essa fase. No Brasil, as discussões entre josé de Alencar e José do Patrocínio em torno do tema da escravatura e da República, podem ser tomadas como exemplos. Nessa fase ganha popularidade a publicação dos romances de folhetim. Os jornais funcionam como incubadores de grandes autores de ficção. Machado de Assis foi um dos que publicaram boa parte de seus romances, primeiramente, em capítulos por meio de jornais, e só depois em forma de livro. Na terceita fase estabelecida por Habermas, há nova mudança no perfil dos veículos de informação, em que o jornalismo chamado literário cede espaço para outra forma de narrativa, privilegiando a informaçào atual. Surge assim o conceito de notícia. A atualidade dos fatos e sua veiculação são as prioridades desta outra forma de imprensa. João do Rio situa-se exatamente nessa transição. 


\section{Virada do século, revirada de idéias}

É fato incontestável que a imprensa ganhou impulso no momento em que as relações sociais deixaram de se basear em meros escambos e a Revolução Industrial trouxe outros parâmetros de negociação para a sociedade. Os jornais aumentaram em número e tiragens para atender a novas demandas surgidas dessa realidade diferente, em que o contato entre as pessoas se torna mais complexo. Segundo Schudson, os jornais do século XIX foram instrumentos vitais para a urbanização, quando as cidades deixaram de ser meras walking-cities, para se tornarem metrópoles modernas, com grandes avenidas, lojas de departamentos e painéis de publicidade. Ler tornarse-ia uma necessidade vital e a alfabetização auxiliou a popularização do saber. 'Jornais, como outros meios impressos, ajudaram a desenvolver um envolvimento crescente na vida pública' (SCHUDSON, 1999, p. 43), a consolidar a cidadania - pela velocidade, acurácia, regularidade e atualidade dos conhecimentos sobre o mundo que traziam.

Quando o século XX chegou, havia ocorrido na literatura algo muito importante na questão das formas de se narrar uma história. Em especial nos dois séculos anteriores, um gênero literário conseguira tornar-se predominante no sentido não só de conquistar o público leitor, mas também de fornecer ao cânone os grandes nomes do período. A épica fora substituída por uma prosa fluente, de caráter mais realista, com aposta na verossimilhança e no efeito do real, em uma narrativa encadeada que, não obstante as diferenças de natureza, parecia ligada à maneira pela qual a sociedade havia aprendido a se informar por meio dos jornais. É a ascensão do romance, como bem diz Ian Watt (1996, p. 170): 'O romance talvez seja o único gênero literário relacionado essencialmente com a palavra impressa: assim, é bastante compreensivel que o primeiro romancista inglês fosse um impressor'. O autor estabelece uma ligação entre o alvorecer do novo gênero literário, a maior popularização da imprensa e a solidificação do capitalismo. Três pilares que, dadas as proporções de importância e amplitude, influenciaram-se mutuamente nos respectivos processos de consolidação.

A expansão do jornalismo no Brasil se deu a partir de 1808 , quando a família real portuguesa se instalou no Rio de Janeiro, mas a reportagem como gênero de narrativa jornalística só surgiu no país no século seguinte, com a consolidação das empresas informativas e 
o reconhecimento da figura do repótter. João Paulo, Paulo Barreto, Joe, Claude, José Antônio José, X. ou simplesmente João do Rio - alguns dos nomes com que assinava os escritos - nasceu em 1881. Vindo de uma familia falida, estreou na imprensa aos 16 anos e entrou com 18 no jornal $A$ Cidade do Rio. Assistiu, menino ainda, aos movimentos da Abolição e da República e testemunhou as reformas urbanas que transformaram o Rio de Janeiro, de uma cidade portuguesa nos trópicos, na afrancesada metrópole da nossa tardia Belle-époqué (RODRIGUES, 1996, p. 72). En 1903, Paulo Barreto entrou na Gazela de Notícias, veículo que tinha a preocupação de inovar c assumia tendências modernizadoras. $O$ jornal tradicional ainda era 'a anêmica, clorótica e inexpressiva gazeta da velha monarquia' (EDMUNDO, apud MEDINA, 1988, p. 47), mas a caricatura deve ao ítalo-brasileiro Angelo Agostini - pioneiro da charge política no Brasil, dentre outros - sua afirmação como gênero. Nesse movimento de renovaçào, as primeiras manchetes e subtítulos começavam a ser testados.

O Rio de Janeiro desse periodo cra um admirárel microcosmo onde as transformaçōes da civilização vinham repercutir em escala miniatural, mas de maneira talve\% mais nítida do que em qualquer outra parte do mundo. A evolução, aqui, fora rápida demais (...) A cletricidade substituía os bicos de gás; os bondes de burros cediam lugar aos tramways da Companhia Jardim Botânico; os velhos tillburis e fiacres iam aos poucos desaparecendo, para dar lugar aos primeiros automóveis; o cinematógrafo fazia concorrência ao teatro; "a Europa curvava-se ante o Brasil", com as descobertas de Santos Dumont... (MARTINS, 1971, p. 13)

O prefeito Pereira Passos ordenara, sob o comando do presidente Rodrigues Alves, uma completa remodelação da cidade do Rio de Janeiro, adotando o slogan: 'O Rio civiliza-se'. Na então capital do pais, a boêmia intelectual iria ceder espaço ao homem apressado do século XX. Nos Estados Unidos, em 1861, The Nem Yorke Times publicara a primeira matéria em formato de piramide invertida, mas a nova forma só iria chegar ao Brasil nos anos 1950. Antonio Candido define esse momento como a 'Época das Luzes' no Brasil, quando se conseguiu sentir um pouco da Ilustração, já tào alastrada e consolidada na Europa há tempos. Uma fase em que ganharam força 
a expansão intelectual, incluindo aí o amadurecimento do jornalismo e da literatura: 'Como orador e jornalista foi que o intelectual definiu então em grande parte a sua posição: e sob tal aspecto apareceria doravante ao público médio, como a própria encarnação da literatura' (CANDIDO, 1997, vol. 1, p. 230).

Não por coincidência, o jornalismo encorpou-se no mesmo período. No primeiro estágio da imprensa nacional, ocorreu no Brasil o mesmo fenômeno visto em outros países. $O$ jornalismo, antes voltado à consolidação da empresa mercantil, rendeu-se a aspectos mais artísticos, tornando-se o que se convencionou chamar de 'literário'. É preciso frisar que, por ser tardio, esse movimento não foi tão bem delineado no Brasil quanto em outras nações. As duas primeiras fases do jornalismo, de acordo com a classificação de Habermas, se confundiram um pouco por aqui. $O$ fato é que, nessa passagem para o jornalismo literário, os escritores invadiram as redações e os veículos passaram a publicar folhetins, textos sem grande objetividade, publicizando a produção literária da época (TRAVANCAS, 2001, p. 25-26).

Martín-Barbero (1987, p. 135-136) lembra que, na incorporação das classes populares à cultura hegemônica, a imprensa ou, como ele chama, a 'indústria de relatos', teve papel fundamental. Nesse período de que estamos tratando, meados do século XIX, a demanda popular e a evolução das tecnologias de impressão fazem da imprensa cenário para o lançamento da produção cultural massiva. $O$ autor considera, nesse contexto, que o folhetim foi o 'primeiro tipo de texto escrito em formato popular de massa' e demarca o aparecimento do primeiro folhetim verdadeiro, escrito em episódios e publicado em série, no ano de 1836, na França. E, como reconhece Barthes, toda a literatura foi afetada pelo folhetim, assim como a vida dos escritores.

O que é relevante não é que Balzac ou Dickens escreveram folhetins - para ganhar a vida -, mas a aparição de um novo tipo de escritura a meio caminho entre informação e ficção, rearticulador de ambas, e a emergência de um novo estatuto social para o escritor, agora profissional assalariado. Por que secretas e sagradas razões o que não implica nenhuma desonra para a escrita desvaloriza a do literato? Será por acaso que a aura expulsa da obra de arte se refugia obstinada no ofício? (MARTÍN-BARBERO, 1987, p. 139) 
Parte do século XIX foi, assim, marcada por essa parceria entre literatura e jornalismo. É a época em que surgem, na multidão dos escritores, algumas figuras que se haviam de ligar nào só à indústria da divulgação da noticia, mas ainda ao jornalismo como revelação de um sentimento literário' (COUTINHO, 1986, p. 64). A proximidade existente entre jornal e livros ocasionou o surgimento de textos híbridos e novas formas de expressão, como informa Maria Isabel Edom Pires:

Podemos notar a persistência da migração de um campo para outro: escritores são também jornalistas. Nesse intercâmbio, cada época formulou suas próprias experiências, algumas em plena vigência. Assim, no início do sćculo XIX, a constituição de gêneros como a crônica e o romance-folhetim contribuiu a seu modo para a profissionalização dos literatos, para sua maior visibilidade na cena cultural e para a democratização) da literatura (PIRES, 2002, p.13-14).

\section{Novos gêneros, novo papel do escritor}

Assim como em outras partes do mundo, os literatos foram, e continuam sendo, presença constante na imprensa brasileira. Isso era ainda mais agudo na fase literária do jornalismo nacional. $O$ que levava tantos escritores a se interessar pelo veículo jornal era a exposição que o meio oferecia a seus trabalhos, além de ser uma oportunidade que se abria para o aperfeiçoamento da produção literária ganhando vencimentos melhores: 'Os homens de letras buscavam encontrar no jornal o que não encontravam no livro: notoriedade, em primeiro lugar; um pouco de dinheiro, se possivel' (SODRÉ, 1983, p. 292). De acordo com Afrânio Coutinho, 'a indústria do noticiário, desenvolvendo-se no ritmo do progresso do pais, transformou os jornais em fontes de lucro para os escritores' (1986, p. 97).

Os jornais e revistas tinham como trunfo servirem de berçário, vitrinc, pedestal e mesmo de trampolim para o homem de letras, encarregando-se do recrutamentes, da visibilidade e dos mecanismos de consagração) dos escritores. Era a imprensa que dava condiçōes de sobrevivência e de divulgação para a produção dessa massa crescente de intelectuais brigando por um lugar ao sol. (COSTA, 2005, p. 25) 
A virada para o século XX constituiu-se, no Brasil, um divisor de águas em diversos campos, o que afetou a relação entre jornalismo e literatura no país. $O$ 'terreno comum da boêmia literária', onde repousavam a literatura e o jornalismo foi surpreendido pelos novos tempos e seus paradigmas. 'A idéia de reconstituir o real ganhava força: 'É esta tarefa, a de sair ao real para coletar dados e retratá-lo, a missão que o jornalismo exige das formas de expressão que passa a importar da literatura, adaptando-as, transformando-as' (LIMA, 1995, p. 137-138). Empreende-se aí uma mudança radical de conceitos. De acordo com Edvaldo. Pereira Lima, a literatura, que antes era fonte para o jornalismo na questão do estilo da escrita, passou a consumidora deste no que tange a um maior realismo das narrações.

Além das questões do discurso, há outras diretrizes para o que existe de mais prático dentro da imprensa: o jeito de fazê-la. Dá-se, aqui, o início do processo de desliteraturização do jornalismo nacional. $O$ caráter predominantemente literário dos jornais vai cedendo espaço, a partir do final do século XIX e início do XX, a uma nova organização. É a transição, como define Habermas, da segunda para a terceira fase do campo jornalístico. O jornalismo ganha nesse processo sua feição moderna, superando a fase em que os periódicos se ligavam apenas nó estilo do texto e se davam ao luxo de negligenciar em parte os fatos da atualidade para se ater a debates de cunho intelectual, abrindo preciosas colunas para a publicação de obras literárias.

No momento em que o jornalismo salta do literário para o informativo é que surge João do Rio e sua invenção. Em verdade, podemos dizer que ele estava no olho desse furacão e participou ativamente do vendaval, não tentando se segurar para não ser carregado pela força dos novos ventos, como fizeram muitos dos colegas, mas soprando cada vez mais forte para que o tornado continuasse arrastando a tudo e a todos. Ele não foi uma figura passiva nesse contexto. Não foi uma mera rosa-dos-ventos. Prevendo novas possibilidades, jogou-se de cabeça nas transformações e esteve na vanguarda delas.

A transformação no perfil da imprensa nacional, inspirada em tendências consolidadas em outras partes do mundo, ocorreu em virtude da profissionalização das relações capitalistas realizadas no meio. Quando o capitalismo se fortalece de maneira mais consistente, e isso é sentido no Brasil, o jornalismo não passa incólume. As novas exigências do público respondem por parte da guinada. Além disso, os literatos se rendem à nova situação, incorporando- 
se ao mecanismo capitalista de transmitir informações: 'O jornalismo desponta no século XIX com um discurso neutro, imparcial, amplo e concreto, capaz de separar fielmente os fatos das opiniões, depois de passar por uma fase ficcionista onde foi confundido com o discurso da literatura' (MARQUES In: MOUILLAUD c PORTO, 2002, p. 528). Era uma opção que diferia totalmente do que vinha sendo feito até aquele momento.

A nova face do jornalismo brasileiro soterrou de vez algumas práticas. Uma delas era a importância dada à literatura dentro dos jornais: 'Vai longe o tempo em que o próprio texto do jornal estava mais próximo da literatura' (TRAVANCAS, 2001, p. 22-23). A extinção gradativa do romance-folhetim na imprensa foi um dos sintomas mais visiveis desse processo: 'Tais alterações scrão introduzidas lentamente, mas acentuam-se sempre: a tendência ao declínio do folhetim, substituído pelo colunismo e, pouco a pouco, pela reportagem' (SODRÉ, 1983, p.296). Isabel Travancas aponta alguns fatores para essa 'desliteraturização', como a ânsia da imprensa local por estar antenada com o que o ocorria no restante do mundo, a modernização das técnicas empregadas para compor um jornal, o privilégio da informação em detrimento da opinião e a maior facilidade de acesso ao livro $(2001$, p. 43). Com menos espaço para exercitar a criatividade e o talento literário, muitos escritores tomaram-se repórteres, cncarregados de cobrir o factual.

As colaborações literárias, aliás, começam a ser separadas, na paginação dos jornais: constitucm matéria à parte, pois o jornal não pretende mais ser, todo elc, literário' (SODRÍE, 1983, p. 297). Werneck Sodré chama a atenção ainda para o efeito colateral dessa realidade, que é a proliferação das revistas ilustradas, refúgio de muitos dos escritores que viram scu espaço no jornal diário drasticamente diminuido (1983, p. 297). Os escritores sofreram pressòes para se adequar à nova rotina de trabalho: 'Aos homens de letras, a imprensa impõe, agora, que escrevam menos colaborações assinadas sobre assuntos de interesse restrito do que o esforço para se colocarem em condições de tedigir objetivamente reportagens, entrevistas, notícias ' (SODRÉ, 1983, p. 296-297). A linguagem objetiva e informativa da imprensa moderna não combinava com divagações literárias: 'Nossos jornais, banhando-se na experiência da objetividade $c$ dependendo diretamente do noticiário telegráfico, apreendcram um novo estilo, scco e forte, que já não tinha qualquer ponto de contato com o beletrismo' (DINES, 1996, p.26). 


\section{Os conflitos de João e o nascimento da notícia}

Sofria Paulo Alberto dilemas quanto à sua condição de jornalista? Filho de um professor de matemática e de uma dona de casa excêntrica, Florência, João perdeu cedo o irmão e depois disso teve todas as atenções da mãe. 'Paulo adorava-a e, em servi-là e satisfazer-lhe a avidez de grandes mimos, empregava a diligência de um enfermeiro alegre por uma doente caprichosa', conta Ana Beatriz Rosa, acrescentando que, do velho Barreto ele herdou a mania dos livros. Segundo essa autora, as condições modestas da família obrigaram o menino a trabalhar. Mas ele tinha, desde-logo, o sonho de ser escritor:

Eu era menino dé primeiras letras e já conhecia Bilac, graças às relações de minha família com casas onde Bilac ia, onde se falava de Bilac. Era no fim de monarquia (...) Há impressões de infância que nos ficam na memória. Nunca mais esqueci aquele momento em que eu era criança, me batia contra um énorme sorvete de creme na Confeitaria Pascal, e ouvi a baronesa de Mamanguape dizer:

- Oh! Senhor Olavo Bilac!

(...) Foi a primeira vez que vi o poeta. Eu desejava ser assim e tinha talvez sete anos.

Com menos de 18 anos; publicou seu primeiro texto - uma crítica da peça Casa de Bonecas, de Ibsen - no jornal $A$ Tribuna. Em 1899 estreou como contista ('Impotência'), no vespertino de José do Patrocínio. Assinava sob o pseudônimo de Claude. Deixando $A$ Cidade do Rio, perambulou por vários jornais e revistas, com um novo e enigmático nome: $\mathrm{X}$. Aos 22 anos, tentou a carreira diplomática, mas foi recusado pessoalmente pelo Barão do Rio Branco. Em 1903, adotou o pseudônimo que o consagraria. Rodrigues (1996, p. 49) aponta que ele teria se inspirado no jornalista do Le Figaro, NapoléonAdrien Marx, o Jean de Paris. 'De Jean de Paris para João do Rio foi um pulo.' De fevereiro a março de 1904, João do Rio publicou a série de reportagens sobre os cultos religiosos na capital carioca, que viriam a constituir, mais tarde, seu primeiro livro, As religiões no Rio. Além da invenção de um novo estilo de escrita jornalística, ele também teve outras preocupações. Com a mäestrina Chiquinha Gonzaga, fundou em 1917 a Sociedade Brasileira" de Autores Teatrais (Sbat), entidade que até hoje se mantém como defensora dos direitos autorais. Ele 
poderia ter ficado rico, pois em 1911 fundou, com Irineu Marinho, o periódico A Noite, embrião das Organizações Globo.

João Paulo Alberto Coelho Barreto tentou três vezes a Academia Brasileira de Letras, tendo sucesso na última vez. Em 1904, ele estampou, na Gazeta de Notícias, uma enquete dirigida aos principais intelectuais da época. Entre as cinco perguntas sobre literatura, uma em especial nos chama a atenção e parece nos dar pistas sobre as dúvidas que inquietavam Joào do Rio: 'O Jornalismo, especialmente no Brasil, é fator bom ou mau para a arte literária?' Ele conseguiu 11 entrevistas e 25 cartas, em resposta às questōes enviadas a 100 pessoas. Três anos depois, reuniu-as no livro Momento Literário, importante documento sobre a vida intelectual de então.

Por que tanta insistência em pertencer à ABL? Jornalista notório, grande parte do material que apresentou em sua primeira qualificação à Academia havia aparecido nas colunas de jornal. Com a atividade cotidiana na imprensa, João já era consideravalmente conhecido da população. Em julho de 1918, ao lançar o livro Correspondência de uma estação de cura - que 'retrata o cotidiano ocioso dos veranistas endinheirados" (EULÁLIO, in RIO, 1992, p. VII) que orbitava numa cidade termal brasileira -, Paulo Barreto deu uma entrevista à Revista da Semana e exibju publicamente o seu drama:

- Mas é impossivel que todos os escritores não vejamo grande momento que atravessamos, para o fixar. Épocas anteriores tiveram fixadores dignos: Alencar, Macedo, o grande Aluisio Azevedo. Só este momento não tem um romancista que o sinta e reflita tal qual é. Entretanto, a vida social do Rio neste periodo de transformação daria para uma obra de história social maior que a de Balzac.

- Eo senhor?

- Eu não tenho tempo! Tenho notas, observações, esquemas para 40 ou 50 volumes necessários, e com 36 anos e a dura luta pela vida é totalmente impossivel realizá-los. Há enredos de livros que resumo em cronicas e contos (...) Creia: a minha dor vem, não da impossibilidade de os escrever eu, mas de não serem eles escritos, já. Tenho um livres sobre os pobres vagabundos, $A$ alma lencantadora] das ruas, que é quase História apesar de escrito há 10 anos, tão vertiginosamente mudam os costumes. Uma novela cujo enredo obtive há 13 anos, Juca de São Jorge, 
foi preciso reescrevê-la, de tal forma que o aspecto íntimo da ralé é outro agora. Que pena não termos o romancista, o relator hercúleo dos nossos costumes!

Brito Broca (apud COSTA, 2005, p. 41) reconhece em Paulo Barreto 'o cronista por excelência do 1900 brasileiro' e ressalta que uma das principais inovações que ele trouxe para a nossa imprensa literária foi a de transformar a crônica em reportagem - passagem por vezes lírica e com vislumbres poéticos'. Com Barreto, o texto cheio de detalhes, diálogos e nome dos entrevistados se afirmou como produto jornalístico. De início, os leitores pensaram que as primeiras grandes reportagens publicadas no século, em nosso país, fossem fantasia, imaginação, como os folhetins. ' $\mathrm{Na}$ época em que apareceram As religiões do Rio, ninguém [...] se interessava por tais assuntos', lembra Luís Martins (1976, p. 9). 'Era um processo desconhecido de buscar e apresentar a informação, um modo ignorado de impressionar e esclarecer o público' (BRITO BROCA, apud MARTINS, 1976, p. 9). João do Rio foi acusado de plagiar um livro publicado na França, Les petites réligions de Paris (As pequenas religiões de Paris). 'A estrutura de $A s$ religiōes no $\mathrm{R} i o^{3}$ é praticamente a mesma. O repórter visitava templos e rituais religiosos, descrevia e explicava os acontecimentos e principais dogmas das religiões' (ROSA, 2003). Porém, de fevereiro a abril de 1900, na Gazeta de Notícias, o transgressor jornalista inaugurou um estilo de narrativa que teria correlação, nos anos 1960, com o New Journalism norte-americano de Tom Wolfe e Gay Talese, e mais tarde com o chamado Gonzo Jornalismo, ou o estilo baseado nas impressões subjetivas do repórter, que se coloca dentro da narrativa.

O processo de apuração de João do Rio era o de um repórter dos tempos modernos: andava na noite, percorrendo os estabelecimentos do submundo carioca, conversando com as pessoas, juntando informações. Ou, como diz Costa $(2005$, p. 42), usava o 'questionamento das fontes, a circulação por diversos bairros em busca de diversidade, o uso privilegiado das descrições in $1000^{\circ}$. Ele deixou um total de 2.478 obras, sendo 2 mil textos publicados em jornais. Aventurou-se pelo romance e pelo teatro, embora seu estilo preferencial fosse o da reportagem sobre o cotidiano. Foi dos primeiros a publicar entrevistas. Sempre se colocou numa posição crítica

3 Embora haja algumas menções ao título deste livro como As religiōes do Rio, o original publicado em 1904 e republicado mais tarde, seria As religiões no Rio. 
ao trabalho no jornalismo, com uma perspectiva ampla dos problemas. Ao fundar o diário A Pátria, expressou uma visão clara, conquanto pessimista, da profissão:

O repórter não tem família. E, para o público, que nem se apercebe de quantos custou o jornal, desesperam-se, todos os dias, todas as horas, todos os minutos, todos os segundos, batalhões de homens. Não têm futuro senão) () do dia seguinte. Que thes importa? O diabo os anima. E, se $\mathrm{cm}$ todas as profissões há a esperança de ser rico - a mais nobre e a mais digna de todas as esperanças -, se no comércio a sociedade espera-nos, se na burocracia a chefia da seção é a meta, no jornalismo o fim é acabar inútil, sem ànimo para correr, atirados para o cantos comos um bagaço. (ROSA, 2003)

Ao analisar o papel da imprensa como instituiçào formadora da modernidade e constituidora do espaço público no Brasil, Lavina Madeira $(2004$, p. 229, 232) reconhece que o autor inovou ao incluir 'novos agentes, novos objetos, práticas, valores e perspectivas sobre a realidade':

João do Rio, de certa forma, brincou com o mundo c com os limites potencialmente abertos de expressão no espaço institucional da comunicação. Ėra, por um lado, uma vo\% de perito - como agente autorizado a formar referencialidades sobre imagens e cxperiências urbanas - mas, por outro, um personagem destas imagens c experiencias explorando a competência do recurso lingüístico em absorver significaçōes criadas para além dos limites racionais da fala exclusivamentc intelectual.

Um legítimo trabalho de mediação, que é uma das características principais do jornalismo moderno. Modernidade que estava entre as principais preocupações do jornalista João do Rio. Na apresentação da recente edição da coletânea Vida Vertiginosa, com textos do autor publicados em jornais na primeira década do século $\mathrm{XX}$, Rodrigues assinala: '..) Seu desejo primordial foi captar a transformação da cidade e da sociedade, que abandonavam as velhas tradições do tempo do império para ingressar na aventura da modernidade' (RODRIGUES In: RIO, 2006c, p. IX e X). $\Lambda$ veia de repórter de Joào do Rio afora 
com mais força dentro de um contexto favorável a isso. Com a proclamação da República, o Rio de Janeiro, já sem a monarquia, passa a uma nova fase, um período de adaptações e remodelações. Algo que está na ponta de lança de um processo que é nacional, o desejo de se integrar ao mundo, com as características que modernidade traz.

$\mathrm{O}$ ambiente urbano daquele Rio de Janeiro era vibrante em muitos aspectos. Havia um desejo coletivo de que o país, e mais especificamente a capital, fosse reconhecido fora de seu âmbito mais restrito, que uma nova mentalidade se instalasse, que houvesse avanços materiais e comportamentais. Por isso a reforma urbana; por isso a necessidade de a imprensa encontrar outras maneiras de agir e interagir. Para um repórter com pouco mais de 20 anos de idade como - Paulo Barreto da época, uma oportunidade e tanto para afirmar uma postura de independência, traçando seu próprio caminho na fronteira - muitas vezes minada - da literatura e do jornalismo. Dizer que João do Rio era um revolucionário de seu tempo por adotar, de forma mais enfática, o papel do repórter e não se identificar com o lugar do escritor dentro das redações, pode não ser uma afirmação precisa. Ele escreveu muita fição. Romance, contos, peças de teatro. E gostava de debater a literatura, haja vista a reunião de perfis sobre o assunto, realizada em O Momento Literário, obra de 1908, cuja idéia inicial foi de Medeiros de Albuquerque e que João do Rio seguiu com minúcia. O livro foi republicado recentemente (Criar Edições, 2006). Ali se percebe o grande repórter nunca se divorciou da literatura. Mesmo que adotando práticas tão jornalísticas, deixando a criação em prol da inquirição e da apuração, jamais abdicou da condição de escritor. É interessante perceber qual era a sua visão do ofício:

O público quer uma nova curiosidade. As multidões meridionais são mais ou menos nervosas. A curiosidade, o apetite de saber, de estar informado, de ser conhecedor são os primeiros sintomas da agitação e da nevrose. Há da parte do público uma curiosidade malsã, quase excessiva. Não se quer conhecer as obras, prefere-se indagar a vida dos autores. Precisamos saber? Remontamos logo às origens, desventramos os ídolos, vivernos com eles. A curiosidade é hoje uma ânsia... Ora, o jornalismo é o pai dessa nevrose, porque transformou a crítica e fez a reportagem." (RIO, 2006b, p. 9) 
A "nevrose", a "curiosidade malsã" Joào do Rio soube satisfazer com incursões no submundo do Rio de Janeiro, visitas a paisde-santo e participação em ritos estranhos, subidas aos morros onde ninguém de sua classe se dispunha a ir. Pequenas aventuras do repórter, que escrevia como escritor e que passou à história como cronista. Um dos majores de todos. Talvez seja justo, já que a crônica é um gênero híbrido por natureza e João do Rio as escreveu em abundância. Com um olhar mais poético e uma prática de redação informativa, ele foi unindo as pontas e fazendo um jornalismo ainda inédito na época, que irritava a uns e encantava a outros. Entre a ficção e a realidade, João do Rio fazia experimentações, tentativas de, a partir de referências tradicionais, realizar o novo, o moderno num terreno que dominava: o da escrita.

\subsection{A notícia como bem simbólico e as transformações no texto}

João do Rio previu que o jornalista seria 'o literato do futuro', a pessoa que 'vê, sente, que sabe porque aprendeu a saber (...), eco de alegria, da ironia, da curiosidade, da dor do público' (MEDINA, 1988, p. 53-39). Embora a Academia Brasileira de Leetras tenha lhe dado o fardão somente em 1910, reconhecendo-o como escritor quando ele tinha 29 anos, os de sua época o vêem como repórter - "com um ar preguiçoso, meio dândi', na definição do pintor Di Cavalcanti. João do Rio parecia um 'personagem das caricaturas', como evoca João Carlos Rodrigues (GRAIEB, 1994). Segundo Rodrigues, 'seus principais traços de caráter eram a inteligência agudíssima e a curiosidade. Era um escritor de estilo vivo, coruscante, como diziam na época'.

'O repórter vaj a campo e busca informações. Vale-se, antes de mais nada, do método da observação. Esta capacidade é apontada por quase todos os autores como a arma mais importante de Paulo Barreto', diz Cremilda Medina (1988, p. 53-59). Com ele, dáse o aprofundamento da grande reportagem e, a partir da década de 1960 , a notícia acerta seu rumo com a tendência interpretativa do jornalismo.

Vamos nos deter em seguida no exame de As religiöes no Rio (1976) para mostrar como João foi o jornalista atuando nas diferentes fases do trabalho de apuração. O repórter parecia seguir o passo-apasso dos repórteres atuais, ao desenvolver suas matérias, a saber: 
1) Pauta - o roteiro para a série de publicações no jornal Gažeta de Notícias seriam as seitas religiosas que 'pululavam' nas ruas do Rio. No trabalho - que causou "uma tão larga hospitalidade e um tão grande ruído" - , o esforço foi o de "levantar um pouco o mistério das crenças'. Partia de convicções próprias, como explica no prefácio do livro:

A religião? Um misterioso sentimento, misto de terror e de esperança, a simbolização lúgubre ou alegre de um poder que não temos e almejamos ter, o desconhecido avassalador, o equivoco, o medo, a perversidade (p. 17).

2) Observação e indexação - Ao listar o que via, apelava para o tratamento pessoal, na tentativa de maior aproximação com o leitor: chamava-o de vós.

(...) A cidade pulula de religiões. Basta parar em qualquer esquina, interrogar. A diversidade dos cultos espantarvos-á. São swenderborgueanos, pagãos literários, fisiólatras, defensores de dogmas exóticos, autores de reformas da Vida, reveladores do Futuro, amantes do Diabo, bebedores de sangue, descendentes da rainha de Sabá, judeus, cismáticos, espíritas, babalaôs de Lagos, mulheres que respeitam o oceano, todos os cultos, todas as crenças, todas as forças do Susto (p. 17).

Ou:

Da grande quantidade de escravos africanos vindos para o Rio no tempo do Brasil colônia e do Brasil monarquia, restam uns mil negros. São todos das pequenas nações do interior da África, pertencem ao ingesá, oié, ebá, aboum, baussá, itaqua, ou se consideram filhos dos ibouam, ixáu dos gêge e dos cambindas (p. 19).

3)Questionamento - O repórter é sempre o indagador, o inquiridor, o perguntador.

- Que é positivismo? sussurro eu, sentando-me (...)

- Como este templo foi feito? (...)

- O Centro também tem uma casa em Paris? (...p. 58-60)

4)Descrição - O repórter viveu três meses no meio dos feiticeiros, das iaôs, das babalorixás, mas não deixou de procurar os positivis- 
tas, evangélicos, católicos, como também os satanistas e as sacerdotisas do futuro. Nessa apuração que caracteriza o aprofundamento da reportagem, ele se detém no cuidadoso trabalho de organizar os dados, avaliá-los, selecionar o que é mais importante e descrever. Ao mesmo tempo em que se envolve como assunto, emociona-se. Ele aponta o que vê, enquadrando o cenário em algum tipo de classificaçào:

Há no Rio magos estranhos que conhecem a alquimia e os filtros encantados, como nas mágicas de teatro, há espiritos que incomodam as almas para fazer os maridos incorrigiveis voltarem ao tálamo conjugal, há bruxas que abalam o invisivel só pelo prazer de ligar dois corpos apaixonados, mas nenhum desses homens, nenhuma dessas horrendas mulheres tem para este powo on indiscutivel valor do Feitiço, do misterioso preparado dos negros (p. 34).

5) Análise, interpretação - A fim de explicar, didaticamente, o que está observando, o repórter tece comparações, analisa e interpreta:

O povo Maronita, dizia o papa Benedito, é como uma for cntre os espinhos. Se o pontifice notácel tinha esta doce frase para pintar os homens do monte Libano, os que the sucederam guardaram tão perfumada imagem, e hoje, quando se fala dos maronitas, logo se recorda a flor e os espinhos antigos. Tudo, porém, neste mundo, tem o vinco fatal do destino. (p. 63)

6) Crítica - No momento de elaborar o texto, nenhum repórter se exime de um certo subjetivismo, fruto das próprias experièncias, seja sob o ponto de vista da ordenação, seja na própria seleção dos fatos. João do Rio, como escrevia na primeira pessoa, dá sua opiniào no próprio texto:

(...) Julgo que seria mais interessante como patologia social estudar, de preferência, aos mercadores da paspalhice, os que lá vão em busca de consosolo.

7)Complementaçāo - Paulo Barreto se preocupa até mesmo com a tabulação dos dados. No capítulo dedicado aos fisiólatras, utiliza gráficos para demonstrar rituais da Ortologia (Lógica Universal) e para apresentar os princípios do Karma, assunto em pauta até hoje. 
A hiperquímica, de byper e da língua universal kim, que significa a parte invisível e indestrutivel da matéria, tem duas ciências preliminares: a alquimia, ou tratado da reação das" matérias em estado das correntes puras, e a químia. O princípio alquímico é que a matéria é uma, vive, evolui e se transforma (p. 75).

\section{Considerações finais}

Como vimos, a invenção de João Paulo Alberto Coelho Barreto tinha todos os ingredientes de atualidade e adequação ao real da moderna reportagem. Se tomarmos a definição dos manuais de redação, poderemos constatar que seu texto nasceu com todas as características da notícia, tal como a concebe a norma clássica do jornalismo (O ESTADO..., 1990)

- humanização - individualiza o fato social através do uso de personagens;

- contexto social - as reportagens tratam de questões sociais que inquietam a sociedade;

- reconstrução histórica - ao contrário da fantasia, dos textos rebuscados e pouco densos em informação, situações vivas e remissão histórica dos fatos.

Rodrigues (1996, p. 15) recorda que, 'como jornalista, João do Rio] foi um inovador histórico da nossa imprensa diária (...) O Rio de Janeiro da bela época é em grande parte uma 'invenção' sua'. Entretanto, não fiquemos apenas na imprensa factual. O new journalism, que surgiu na década de 1960 nos Estados Unidos e seria uma reação à objetividade e distanciamento dos fatos, também é caudatário de João do Rio e do estilo que se chamou mais tarde jornalismo literário. Se o jornalismo norte-americano, difundido pelas agências de notícias, ficou preso ao modelo da pirâmide invertida e aos parâmetros das sete perguntas do lide sumário, o novo jornalismo de John Reed e Tom Wolfe bebeu das mesmas fontes de João do Rio - a literatura - e desaguou em um novo padrão de narrativa.

Um texto em que o narrador tem voz própria e persegue um estilo individual, envolvendo-se com os fatos e sua captação. Para esse processo de apuração que descobriu no contato com as ruas, João inventou uma expressão: "Flanar! (...) É ser vagabundo e refletir, é ser basbaque e comentar, ter o vírus da observação ao lado da vadia- 
gem. Flanar é a distinção de perambular com inteligência. Nada como o inútil para ser artístico." Exatamente como preconizam os Gonzo jornalistas e como fazia João do Rio em cada esquina, em cada praça. Esse exercício diário o tornou uma espécie de herói das multidões que ele defendeu e retratou: a multidào de 100 mil trabalhadores humildes, marinheiros e prostitutas, mulheres exploradas, capoeiras, negros e imigrantes, anônimos, escritores, jornalistas, presidentes e notórios que o levou ao túmulo, antes de completar 40 anos, em 23 de julho de 1921, encerrando um ciclo e começando outro no jornalismo e na literatura brasileiros.

Observamos, portanto, que Joào do Rio - e o que chamamos sua imvenção, a reportagem - foram frutos de duas tendências. Em primeiro lugar, situações socioculturais marcantes na vida brasileira, derivadas justamente dos movimentos políticos pela aboliçào da escravatura e a decretação da República. Em segundo, correntes de vanguarda européias que, antes da I Guerra, já vinham transfigurando as heranças do Realismo e do Decadentismo. Novas tecnologias despontavam: o telégrafo, o fonógrafo, o cinematógrafo, o daguerreótipo e novos métodos de impressão, com máquinas que aceleravam a produção gráfica. Todo esse panorama contribuiu para a profissionalizaçào dos mestres do texto: escritores e jornalistas.

Também constatamos que, além da reportagem e da entrevista, a notícia se afirmou como gênero textual, ao lado de outros gêneros literários - o romance, o folhetim e a crónica. Ao mesmo tempo, as pessoas aprendiam a valorizar a informação como instrumento para o desenvolvimento de valores, como a vida em sociedade, o respeito aos direitos e à cidadania, exigindo atenção às desigualdades econômicas, culturais e sociais.

Uma nova revolução de linguagem/texto seria necessária para colocar o jornalismo brasileiro definitivamente no contexto internacional, o que só aconteceu depois da II Guerra, com Samuel Wainer, Joel Silveira e Pompcu de Sousa, dentre outros. Com a TV, na década de 1950 e o aperfeiçoamento dos processos de transmissão de notícias e da fotografia, os jornais melhoraram seu padrão, fundaram departamentos de pesquisa e se propuseram a acrescentar dados à notícia. O aumento das tiragens e uma maior rapidez na impressão impulsionaram o jornalismo em busca de padrões industriais. No dizer de Robert Clark, "publicada e reconhecida a sua significação, o que era notícia, transforma-se em história" (apud MEDINA, 1988, p. 66). 


\section{Referências}

BOSI, Alfredo. História concisa da literatura brasileira. São Paulo: Cultrix, 1994.

CANDIDO, Antonio. Formasão da literatura brasileira (2 volumes). Belo Horizonte: Itatiaia, 1997.

COSSON, Rildo. Romance-reportagem: o gênero. Brasilia: 2001, UnB e Imprensa Oficial.

COSTA, Cristiane. Pena de aluguel. Escritores jornalistas no Brasil 1904-2004. São Paulo: Companhia das Letras, 2005.

COUTINHO, Afrânio. A literatura no Brasil. Rio de Janeiro: José Olympio, 1986.

DINES, Alberto. O papel do jornal: uma releitura. São Paulo: Summus, 1996.

EDMUNDO, Luís. Rio de Janeiro do meu tempo, in MEDINA, Cremilda. Notícia, um produto à venda. São Paulo: Summus, 1988.

EULALIO, Alexandre. Apresentação. In RIO, João. A correspondência de uma estafão de cura. São Paulo: Scipione, 1992.

GENRO FILHO, Adelmo. O segredo da pirâmide: para uma teoria marxista do jornalismo. Porto Alegre: Ortiz, 1989.

GRAIEB, Carlos. O dândi João do Rio ganha biografia. O Estado de S. Paulo, 5 nov.1994, caderno D, p. 1.

LIMA, Edvaldo Pereira. Páginas ampliadas. o livro-reportagem como extensão do jornalismo e da literatura. Campinas: 1995, Unicamp.

MARQUES, Francisca Ester de Sá. O processo de televisamento do texto jornalístico. In: MOUILLAUD, Maurice e PORTO, Sérgio Dayrell (org.). O jornal: da forma ao sentido. Brasília: UnB, 2002.

MARTÍN-BARBERO, Jesús. De los medios a las mediaciones. Comunicación, cultura y hegemonía. México: Gustavo Gili, 1987.

MARTINS, Edmilson. João do Rio: a cidade e o poeta - olhar de flâneur na belle-époque tropical. Rio de Janeiro: FGV, 2000.

MARTINS, Eduardo (org.) Manual de redação e estilo. O Estado de S. Paulo. São Paulo: OESP, 1990.

MARTINS, Luís. João do Rio (Uma antologia). Rio de Janeiro: Instituto Nacional do Livro, 1971.

MEDINA, Cremilda. Noticia, um produto à venda: jornalismo na sociedade urbana e industrial. São Paulo: Summus, 1988.

- Profissão jornalista: responsabilidade social. Rio de Janeiro: Forense Universitária, 1982. 
PIRES, Maria Isabel Edom. O jornalista na literatura brasileira contemporânea: algumas notas. In: (org.). Estudos de Literatura Brasileira Contemporânea: Literatura e Jornalismo. Brasília: 1BC - Grupo de Estudos em Literatura Brasileira Contemporânea, n. 17, jan./ fev. 2002.

RIO, Joâo do. As religiòes no Rio. Rio de Janeiro: José Olympio, 2006a; Rio de Janeiro: Nova Aguilar, 1976.

Scipione, 1992. - A correspondência de tuma estação de cura. Sào Paulo: . O momento literánio. Curitiba: Criar, 2006b. Vida vertiginosa. São Paulo: Martins Fontes, 2006c. RODRIGUES, Antonio. - (Joe). Cinematograpbo, Gazeta de Notícias, setembro de 1907, in Rosa, 2003.

RODRIGUES, João Carlos. Jocio do Rio. Uma biografia. Rio de Janeiro: Topbooks, 1996.

ROSA, Ana Beatriz G. Cardoso. João do Rjo ou o indiscreto charme da transgressão. Monografia. Brasília, 2003.

SODRÉ, Nelson Werneck. História da imprensa no Brasil. São Paulo: Martins Fontes, 1983.

TRAVANCAS, Isabel. O liwro no jornat: os suplementos literátios dos jornais franceses e brasileiros nos anos 90. Cotia, SP: Ateliê, 2001.

WATT, lan. A ascensão do romance. São Paulo: Companhia das Letras, 1996. 
